\title{
Hypersensitivity to glucorticoids in children
}

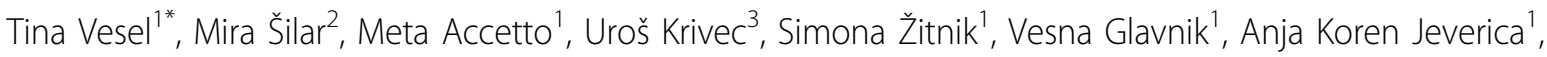 \\ Mitja Košnik ${ }^{4}$, Peter Korošec ${ }^{2}$, Tadej Avèin ${ }^{1}$ \\ From 6th Drug Hypersensitivity Meeting (DHM 6) \\ Bern, Switzerland. 9-12 April 2014
}

\section{Introduction}

Immediate hypersensitivity to glucocorticoids is rarely reported, especially in children. Assessment of crossreactivity after immediate hypersensitivity to intravenous methylprednisolone (MP) usually shows a tolerance to at least one of the alternatives, e.g. MP tablet, hydrocortisone (HC) or dexamethasone (DX).

\section{Methods}

We present 8 children with suspected hypersensitivity reaction after parenteral MP (6 children), DX inhalation (1 child) and inhafluticasone propionate (FL) (1 child). Prick and intradermal skin testing with MP, HC, DX and FL were performed. In case of negative skin tests provocation tests were performed. Basophil activation test (flow cytometry analyses of basophil CD63 surface expression induced by different concentrations of MP, HC, DX and FL $(333,33,3$ and $3,33 \mathrm{mcg} / \mathrm{ml})$ ) was performed in all patients and in ten controls who tolerated those drugs. Stimulation index $(\mathrm{SI})>2$ was considered positive.

\section{Results}

All children ( 5 boys, 3 girls) were atopics and were exposed to various glucocorticoids before systemic hypersensitivity reaction. In 7 children allergy to culprit glucocorticoid was confirmed. 6 children had positive results of either skin testis or provocation test with three or four glucocorticoids and 2 children to MP only. Four children had also positive results of either skin testing or provocation test to FL. In three children positive provocation test after negative skin test confirmed allergy to glucocorticoid. BAT was positive in 6 children: $5 \mathrm{MP}, 3 \mathrm{HC}, 5 \mathrm{DX}, 3 \mathrm{FL}$. One child with positive skin test to MP had negative BAT. One child was BAT nonresponder. One child who tolerated FL had positive

'University Children's Hospital, University Medical Center, Department of Allergology, Rheumatology and Clinic, Slovenia

Full list of author information is available at the end of the article
BAT to FL. BAT to MP, DX, HC was negative in all ten controls $(\mathrm{SI}<1)$. However, BAT with nasal drops of $\mathrm{FL}$ was positive in 3 controls $(2<\mathrm{si})$.

\section{Authors' details \\ ${ }^{1}$ University Children's Hospital, University Medical Center, Department of Allergology, Rheumatology and Clinic, Slovenia. ${ }^{2}$ University Clinic of Respiratory and Allergic Diseases, Laboratory for Clinical Immunology and Molecular, Slovenia. '3niversity Children's Hospital, University Medical Center, Ljubljana, Department of Pulmonology, Slovenia. ${ }^{4}$ University Clinic of Respiratory and Allergic Diseases, Department of Allergology, Slovenia.}

Published: 18 July 2014

doi:10.1186/2045-7022-4-S3-P143

Cite this article as: Vesel et al:: Hypersensitivity to glucorticoids in children. Clinical and Translational Allergy 2014 4(Suppl 3):P143.

\section{Submit your next manuscript to BioMed Central and take full advantage of: \\ - Convenient online submission \\ - Thorough peer review \\ - No space constraints or color figure charges \\ - Immediate publication on acceptance \\ - Inclusion in PubMed, CAS, Scopus and Google Scholar \\ - Research which is freely available for redistribution \\ Submit your manuscript at www.biomedcentral.com/submit}

C Biomed Central

(c) 2014 Vesel et al; licensee BioMed Central Ltd. This is an Open Access article distributed under the terms of the Creative Commons Attribution License (http://creativecommons.org/licenses/by/4.0), which permits unrestricted use, distribution, and reproduction in any medium, provided the original work is properly cited. The Creative Commons Public Domain Dedication waiver (http:// creativecommons.org/publicdomain/zero/1.0/) applies to the data made available in this article, unless otherwise stated. 